\title{
The Impact of Environmental Regulations, Corruption and Economic Freedom on Economic Growth: Empirical Evidence from China
}

\author{
Najla Shariff Omar Al Baiti ${ }^{1}$, Navaz Naghavi ${ }^{1} \&$ Benjamin Chan Yin Fah ${ }^{2}$ \\ ${ }^{1}$ Faculty of Business and Management, Asia Pacific University of Technology \& Innovation (APU), Malaysia \\ ${ }^{2}$ Chair, Centre of Socioeconomic of Ageing (APU), Technology Park Malaysia, Kuala Lumpur, Malaysia \\ Correspondence: Benjamin Chan Yin Fah, Chair, Centre of Socioeconomic of Ageing (APU), Technology Park \\ Malaysia, Kuala Lumpur, Malaysia.
}

Received: August 28, 2017

Accepted: October 9, 2017

Online Published: October 15, 2017

doi:10.5539/ijef.v9n11p92

URL: https://doi.org/10.5539/ijef.v9n11p92

\begin{abstract}
The purpose of this study is to investigate the impact of environmental regulations, corruption and economic freedom on economic growth in China. Different indices were used as measurements of the variables; Environmental Policy Stringency Index, Control of Corruption Index and Economic Freedom of the World Index. The study uses quantitative methods to empirically determine which factors play a role in China's progressive economic growth rates. Unit root test, Johansen cointegration and the Autoregressive Distributed Lag (ARDL) modelling were applied to examine the short and long run correlations. Results indicated that there is in fact a correlation between environmental regulations, corruption, economic freedom and economic growth. Long run coefficients demonstrated that environmental regulations had a negative impact on economic growth, while corruption and economic freedom displayed positive results. However, short run coefficients showed that environmental regulation is insignificant in the short run, corruption maintains a positive impact and economic freedom negatively effects economic growth in the short run.
\end{abstract}

Keywords: economic freedom, economic growth, panel data analysis

\section{Background of the Study}

China's achievements raise the question about what factors contribute to its high economic growth rate. The question of what determines and fuels economic growth appears to be unsolved. In the present reality, economic growth is extremely important and understanding the different factors which contribute to it seems vital. The significance of this issue has led to this problem statement.

Recent research has investigated the effects of environmental policy resulting from China's 2001 accession to the WTO where it was found that even though China had adopted and implemented stronger environmental regulations it did not guarantee better environmental conditions (Long et al. as cited in Tang et al., 2017). In fact, according to Yuan, Ren, and Chen (2017), it is difficult for China to achieve a win-win outcome in terms of both environmental protection and economic development under the current level of environmental regulation. This implies a trade-off between economic growth and environmental protection, indicating that there may in fact be a correlation between current stringency of environmental regulations and economic growth.

According to the Transparency International (2016) China is considered a corrupt nation. Pulok and Ahmed (2017) claim that despite this high-perceived level of corruption, China has managed to "perform well to sustain a good GDP growth rate." In addition, based on empirical literature, it was found that in China corruption facilitates economic growth (Freckleton, Wright, \& Craigwell, 2012). This research aims to further explore in order to support the literature and study its impact combined with the other variables.

According to Taylor (2016) China's economic growth is the effect of the introduction of greater economic freedom in 1979. More attention was being paid to limiting the role of government, more predicatable policy, the use of markets and the rule of law. However, according to Economic Freedom Index, China is considered mostly "unfree". Therefore, it is important to empirically find whether economic freedom has in fact had an impact in fueling China's economic growth.

\section{Literature Review}

There is lack of consensus among researches on the effect of environmental regulation on economic growth. On 
one hand, there is new strand in the literature claiming that environmental regulation enhances economic growth. Economists such as Michael Porter have stated that environmental regulations foster competitiveness and economic growth among industries (Porter as cited in Thomas, 2009). In the same vain, other proponents of more stringent environmental regulations have claimed that the increase in stringency provides firms with an incentive to develop less costly ways of reducing pollution that in turn reduce costs of production (Stewart, 1993). Similarly, Thomas (2009) contends that this incentive not only reduces costs of production but can also increase firm productivity which in turn leads to greater economic growth. Similarly, Wang and Shen (2016) explain that regulation promotes innovation which in turn increases resource efficiency leading to a reduction in the cost of environmental compliance. Thus in this strand of literature, environmental regulation is viewed as a win-win strategy that leads to improved environmental quality, higher productivity and therefore enhances economic growth.

On the other hand, another strand of "stereotype view" asserts that environmental regulation adversely affects economic growth through the imposition of constraints on industry behaviour (Wang \& Shen, 2016). This group of literature which mainly stems from standard economic theory elaborates that long-term effects of environmental regulations on the economy cause decline in productivity and standard of living, then a reduction in economic growth (Thomas, 2009). It is argued that even though environmental regulations assist in limiting harmful effects on the natural environment, the stringent regulations increase business costs related to environmental compliance (Ramanathan et al., 2016). Furthermore, an unintended consequence of environmental regulations, is that firms may respond by moving production to countries with less environmental stringency resulting in significant job loss in the locations left behind (Cai, Lu, Wu, \& Yu, 2016). Cai et al. (2016) study on China has shown that tough environmental regulations drive away FDI which inturn decreases GDP. Another justification for adverse effect of economic growth is that environmental regulation negatively influences international trade which in turn slows down economic growth (Wang, Zhang, \& Zheng, 2016). This effect is elaborated further by Cagatay and Mihci (2006) who found that environmental stringency does in fact weaken a nation's competitive position, thus diminishing exports and significantly impacting international trade patterns. This change on trade flow patterns leads to a deterioration of an economies growth rate in the long run. Hence, it is appropriate to re-examine the correlation between environmental policies and economic growth to achieve comprehehsive findings in case of China.

The question on whether corruption is detrimental to economic growth has long been studied by numerous researchers. Yet, there is no consensus in the literature on the role of corruption. Some studies show positive impact of corruption on economic growth, arguing that corruption can smoothly increase the rate of economic growth by speeding up transactions, particularly in countries with ineffective institutions (D'agostino et al., 2016). Huang (2016) suggests that in certain developing countries, corruption in fact helps in eliminating certain barriers to economic development. Saha and Ben-Ali (2017) elaborate that corruption may have a positive impact by "greasing the wheels of economy" as it may help in minimizing costs caused by redundant bureacratic activities. It is argued that corruption is beneficial for economic growth by avoiding bureaucratic regulations that may be "cumbersome" (Mendez \& Sepulveda, 2006). Furthermore, several economists believe that corruption enhances economic growth in certain cases; some found that in order to maximize economic output there should exist an optimum level of corruption and others found that while corruption may have a negative effect on growth, this effect has a diminishing impact and becomes insignificant (Huang, 2016). Moreover, Dzhumashev (2014) found in his empirical research that corruption may be beneficial for growth, specifically in environments where size of the government exceeds optimal level. Therefore, in such cases, corruption may reduce government size and bring it closer to the optimal level consequently enhancing efficieny and growth. Despite the immense literature on positive role of corruption for economic growth in specific countries at certain times, the mainstream literature concludes that corruption negatively impacts growth. The predominant view is that corruption is as detrimental to economic performance as both market distortion and tax on productivity are (Drury et al., 2006). According the World Bank (2009), several countries such as South Korea, Hong Kong, Malaysia, Indonesia, Singapore, Thailand and the Philippines have experienced around 7\% increase in the economic growth rate in the period of 1986-1996, while the rest of the world have witnessed $2.5 \%$ increase while maintaining high levels of corruption. This implies a negative correlation between corruption and economic growth. There is nearly a consensus about corruption in the theories that it is harmful for a country's economy; it hampers both private and government investment spending, discourages investments, inhibits efficiency of public servies, distorts income distribution, harms democracy and leads to waste of resources (Bayar, 2011). To sum up, corruption impact on economic growth has created two positions. The first, more agreed upon view is that corruption is damaging for a society. The second view is that corruption creates an economic equilibrium in countries that are extremely bureacratic (Drury et al., 2006). 
In this modern era, that "globalization" is treated widely in most parts of the world, the effects of economic freedom has received focus in growth literature. Deeply rooted in classical economic theories, the extensive recent literature has shown that policies promoting economic freedom are viewed as a link towards sustainable economic growth (Gharleghi, Najia, \& Chan, 2015; Farhadi et al., 2015). Less government participation into an economy, less corruption and strong property rights are desirable components for an economy conducive to long-run growth (Moussaa et al., 2016). However, more recent research have found that the correlation between the two variables is not entirely robust across all studies (Compton, Giedeman, \& Hoover, 2011). The authors state that the correlation between economic freedom and growth depends on what components of freedom are used. Economic freedom is measured through focus on five major areas; size of government, legal system and security of property rights, sound money, freedom to trade internationally and regulation (Fraser Institute, 2017). Within these areas there are 24 components. These components focus on key areas of the economic environment in which governments exercice control and policies.

\section{Research Methodology}

The time series data set consists of 21 observations from the years 1995-2015 for China. Firstly, in order to quantify the environmental regulations, the OECD's Environmental Policy Stringency (EPS) Index is used shown as "ENV" in our model. This index measures the stringency of a nation's environmental regulations, and this measurement is defined as the explicit or implicit cost of environmentally harmful behaviour (OECD, 2016). Secondly, this study used Control of Corruption index produced by the World Bank represented by "COR" in the while estimating the model. This index attempts to capture the extent to which public power is exploited for private gain which includes both grand and petty forms of corruption (World Bank, 2017). Thirdly, to measure the economic freedom, the Economic Freedom of the World Index created by Fraser Institute is used. The mentioned index provides data on property rights, trade freedom, business freedom, and fiscal freedom over 1995-2015. It is shown in abbreviated form of "EFREE" in the model estimation process.

The research is a time series study and the statistical analysis used is a combination of data testing methods including unit root test, cointegration (Johansen) and residual diagnostics tests, as well as autoregressive distributed lag (ARDL) model to estimate the model using the collected data.

\section{Research Findings}

To proceed with the cointegration test and ARDL model, the first step is to conduct a unit root test to determine the stationarity of the time series data and their order of integration. This study uses the ADF unit root test and the result is presented in Table 1 .

Table 1. Intermediate ADF test results

\begin{tabular}{ccccc}
\hline Series & Prob. & Lag & Max Lag & Obs \\
\hline LN_EG & 0.6078 & 0 & 4 & 20 \\
LN_ENV & 0.9841 & 0 & 4 & 20 \\
LN_COR & 0.2943 & 0 & 4 & 19 \\
LN_EFREE & 0.0637 & 0 & 4 & 19 \\
\hline
\end{tabular}

Since all variables have a unit root, one of the common ways to make them stationary is to apply the first difference. As presented in Table 2 below, the ADF unit root test shows that the null hypothesis can only be rejected after the first order differencing I(1) for all the variables at 5\% level of significance. This is evidenced by the ADF test results at the first difference where all the P-values were less than 0.05 indicating stationarity of the time series. It can be concluded that all the variables are non-stationary at level and only become stationary after first order differencing. Thus, all variables are integrated of order one I(1).

Table 2. ADF unit root test at first difference

\begin{tabular}{ccccc}
\hline Series & Prob. & Lag & Max Lag & Obs \\
\hline D(LN_EG) & 0.0092 & 0 & 4 & 19 \\
D(LN_ENV) & 0.0445 & 0 & 4 & 19 \\
D(LN_EFREE) & 0.0128 & 0 & 3 & 18 \\
D(LN_COR $)$ & 0.0025 & 0 & 3 & 18 \\
\hline
\end{tabular}

The Johansen cointegration test is applied to determine the existence of a long run equilibrium among the variables in the research. The test is used in this research to conclude whether economic growth, environmental regulations, corruption and economic freedom are cointegrated. 
The results in Table 4 indicate that the null hypothesis of no cointegration is rejected for the rank of zero at $5 \%$ significance level. This is because both the trace statistic and maximum eigenvalue are bigger than the 5\% critical value. However, at rank 1 the null hypothesis cannot be rejected at 5\% level of significance as the trace statistic and maximum eigenvalue are smaller than the 5\% critical value. Thus, it can be concluded that there is one cointegrating equation indicating the existence of a long run correlation between the variables.

Table 3. Unrestricted Cointegration Rank Test (Trace)

\begin{tabular}{|c|c|c|c|c|}
\hline Hypothesized No. of CE(s) & Eigenvalue & Trace Statistic & 0.05 Critical Value & Prob.** \\
\hline None $*$ & 0.915847 & 66.41504 & 47.85613 & 0.0004 \\
\hline At most 1 & 0.622606 & 24.33794 & 29.79707 & 0.1865 \\
\hline At most 2 & 0.349430 & 7.772045 & 15.49471 & 0.4901 \\
\hline At most 3 & 0.026904 & 0.463636 & 3.841466 & 0.4959 \\
\hline \multicolumn{5}{|c|}{ Trace test indicates 1 cointegrating eqn(s) at the 0.05 level } \\
\hline \multicolumn{5}{|c|}{$*$ denotes rejection of the hypothesis at the 0.05 level } \\
\hline \multicolumn{5}{|c|}{ **MacKinnon-Haug-Michelis (1999) p-values } \\
\hline \multicolumn{5}{|c|}{ Unrestricted Cointegration Rank Test (Maximum Eigenvalue) } \\
\hline Hypothesized No. of CE(s) & Eigenvalue & Max-Eigen Statistic & 0.05 Critical Value & Prob.** \\
\hline None $*$ & 0.915847 & 42.07710 & 27.58434 & 0.0004 \\
\hline At most 1 & 0.622606 & 16.56589 & 21.13162 & 0.1935 \\
\hline At most 2 & 0.349430 & 7.308410 & 14.26460 & 0.4533 \\
\hline At most 3 & 0.026904 & 0.463636 & 3.841466 & 0.4959 \\
\hline \multicolumn{5}{|c|}{ Max-eigenvalue test indicates 1 cointegrating eqn(s) at the 0.05 level } \\
\hline \multicolumn{5}{|c|}{$*$ denotes rejection of the hypothesis at the 0.05 level } \\
\hline \multicolumn{5}{|c|}{ **MacKinnon-Haug-Michelis (1999) p-values } \\
\hline
\end{tabular}

The ARDL model is used to empirically analyse the dynamic interaction and long and short run correlation of the dependent variable with the independent variables. The first step in this model is to confirm cointegration through bound testing, then selecting the best model using selection criteria. After the best model is selected, the coefficients for long run and short run are calculated using the ARDL model (Pesaran \& Shin, 1995).

Because the order of integration of all variables is not $\mathrm{I}(2)$ as shown in Table 2, it is appropriate to apply the cointegration bounds test which is the first step in the ARDL test. The bounds test for long run correlation is displayed as follows:

$$
\begin{gathered}
\Delta L N_{E G}=\beta_{0}+\sum_{i=1}^{k} \beta_{1} \Delta L N_{E G_{t-1}}+\sum_{i=1}^{k} \beta_{2} \Delta L N_{E N V_{t-1}}+\sum_{i=1}^{k} \beta_{3} \Delta L N_{C O R t-1}+\sum_{i=1}^{k} \beta_{4} \Delta L N_{E F R E E_{t-1}} \\
+\lambda_{1} L N_{-} E G_{t}+\lambda_{2} L N_{-} E N V_{t}+\lambda_{2} L N_{-} C O R_{t}+\lambda_{2} L N_{-} E F R E E_{t}+\varepsilon_{t}
\end{gathered}
$$

Table 4 displays the calculated F-statistic as well as the critical value bounds. Using the critical values, the null hypothesis of no cointegration is rejected at the $10 \%$ and $5 \%$ level of significance. This is because the F-statistic is higher than the upper value bounds at the $10 \%$ and $5 \%$ significance level. Thus, according to the results shown in Table 4, it is statistically confirmed that a long run economic correlation exists among economic growth, environmental regulations, corruption and economic freedom. These results are similar to the results produced by the Johansen cointegration test which also confirmed cointegration. Therefore, it is possible to proceed with the ARDL test.

Table 4. ARDL bound test

\begin{tabular}{lcc}
\hline Test Statistic & Value & $\mathrm{K}$ \\
\hline F-statistic & 4.390097 & 3 \\
Critical Value Bounds & & \\
Significance & I0 Bound & I1 Bound \\
$10 \%$ & 2.72 & 3.77 \\
$5 \%$ & 3.23 & 4.35 \\
$2.5 \%$ & 3.69 & 4.89 \\
$1 \%$ & 4.29 & 5.61 \\
\hline
\end{tabular}

The lag selected for the estimated long run ARDL cointegration model shown in Table 4, is determined by applying the Akaike Information Criterion (AIC). For this model, the AIC automatically determined the lag of the model to be $(2,0,2,2)$ as displayed in Figure below. 


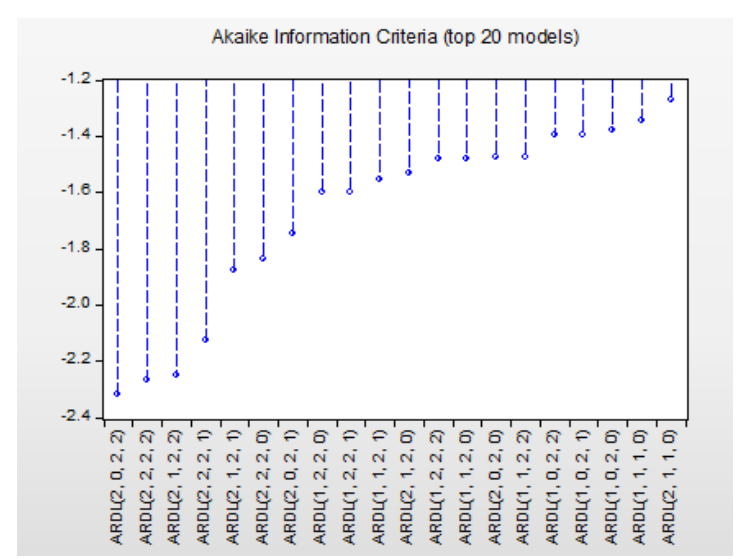

Figure 1. Model selection value

The graph presented in Figure 1 shows the model selection value for the twenty best models and an ARDL $(2,0,2,2)$ was selected as it had the lowest criterion value which is preferred. The next step after selecting the best model is to analyse the long and short run coefficients. After the lag selection and existence of long run correlation is confirmed, then the error correction model is represented as follows:

$$
\begin{gathered}
\Delta L N_{E G}=\beta_{0}+\sum_{i=1}^{k} \beta_{1} \Delta L N_{E G_{t-1}}+\sum_{i=1}^{k} \beta_{2} \Delta L N_{E N V_{t-1}}+\sum_{i=1}^{k} \beta_{3} \Delta L N_{C O R_{t-1}}+\sum_{i=1}^{k} \beta_{4} \Delta L N_{E F R E E_{t-1}} \\
+\lambda E C T_{t-1}+\varepsilon_{t}
\end{gathered}
$$

Table 5. The long-run ARDL cointegration model $(2,0,2,2)$

\begin{tabular}{ccccc}
\hline Variable & Coefficient & Std. Error & t-Statistic & Prob. \\
\hline LN_ENV & -0.371220 & 0.061489 & -6.037180 & 0.0005 \\
LN_COR & 0.555734 & 0.082437 & 6.741281 & 0.0003 \\
LN_EFREE & 1.374778 & 0.665719 & 2.065101 & 0.0778 \\
\hline
\end{tabular}

Table 5 displays the result of long run ARDL model with economic growth as the dependent variable. The coefficients of environmental factors, Corruption and economic freedom are all statistically significant at the $10 \%$ level. Environmental regulation is negative and significant at the 5\% level of significance indicating that a $1 \%$ increase in stringency of environmental regulations will lead to a decrease of economic growth of China by $0.37 \%$ in the long run. This may be a result of China's significant contribution to environmental pollution that has risen due to the country's rapid economic development and international trade. This implies that the country is struggling to balance between environmental reservation and economic growth. Therefore, more stringent policies may in fact adversely impact development as it would drive away FDI and production to countries with less regulations.

After confirming the long run correlation among variables and analysing the long run coefficients of the variables, the next step is to move for short run coefficients displayed in Table 6.

Table 6. The short-run ARDL cointegration model $(2,0,2,2)$

\begin{tabular}{lrcrc}
\hline \multicolumn{5}{c}{ Cointegrating Form } \\
\hline Variable & Coefficient & Std. Error & t-Statistic & Prob. \\
\hline D(LN_EG(-1)) & 0.619471 & 0.209271 & 2.960131 & 0.0211 \\
LN_ENV & -0.077580 & 0.063521 & -1.221333 & 0.2615 \\
D(LN_COR) & 0.129963 & 0.083939 & 1.548305 & 0.1655 \\
D(LN_COR(-1) & 0.630947 & 0.149869 & 4.209981 & 0.0040 \\
D(LN_EFREE) & -6.240284 & 2.140029 & -2.915981 & 0.0225 \\
D(LN_EFREE(-1) & -4.367006 & 1.654610 & -2.639297 & 0.0335 \\
C & -5.143960 & 1.039305 & -4.949423 & 0.0017 \\
CointEq(-1) & -0.954015 & 0.234073 & -4.930161 & 0.0017 \\
\hline R-squared & 0.945985 & Mean dependent var & & -2.367267 \\
Adjusted R-squared & 0.876537 & S.D. dependent var & & 0.186965 \\
S.E. of regression & 0.065694 & Akaike info criterion & & -2.318436 \\
\hline
\end{tabular}




\begin{tabular}{lllr}
\hline Sum squared resid & 0.030210 & Schwarz criterion & -1.828311 \\
Log likelihood & 29.70671 & Hannan-Quinn criter. & -2.269717 \\
F-statistic & 13.62155 & Durbin-Watson stat & 2.097601 \\
Prob(F-statistic) & 0.001175 & & \\
\hline
\end{tabular}

The short run results indicate that environmental regulation stringency has a negative impact on economic growth and a $1 \%$ increase in stringency leads to $0.07 \%$ decrease in growth. The stringency impact of environmental regulations however is not significant in the short-run. Therefore, it can be deduced that stringency only contributes to economic growth in the long run. Corruption on the other hand is significant with a positive coefficient of 0.63 . The short run results indicate that similar to the long run corruption positively impacts economic growth. This is in line with most of the literature that claims that corruption may grease the wheels in the short run, however it contradicts the long-term effects of corruption that claim will lead to problems for economic growth and development (Farooq et al., 2013; Pulok \& Ahmed, 2017). This implies China's uniqueness, as a country with high corruption that has somehow managed to benefit from such activities over the past decades. As mentioned before, gains from corruption serve as incentives for China's government officials which in the short and long run actually encourages investments and economic growth. The elasticities of corruption are not statistically different from each other which indicates that this variable has a consistent and lasting effect.

\section{Conclusion}

This research applies the ARDL bounds test approach to study the correlation between environmental regulations, corruption, economic freedom and economic growth in China for the period of 1995-2015. It was found that the stringency of environmental regulations has a significant negative effect on the economic growth of China in the long run but is insignificant in the short run. This implies that the laxer the regulations become over time, the higher the economic growth rate in China. Therefore, it can be understood that the more stringent China's environmental regulations are, the country will face a consequent decline in economic growth rates. However, the impact is not that strong with a coefficient of 0.37. This implies that although stringency of environmental regulations does in fact contribute to economic growth rates, there are other forces that play more significant roles.

Results also indicated that corruption has a positive and significant effect on economic growth of China in both the short and long run. This finding is in favour of the "grease the wheels" term that claims corruption has a positive impact on economic growth contradicting economic growth theories and therefore, China's low scores on the corruption index are well justified based on the findings of this research. Given the size of its economy and perceived high corruption levels, the country seems to be a notable exception to the findings in economic growth literature that claim the "grease the wheels" concept may be positive in the short run but will lead to long term problems.

Economic freedom has a significant positive and significant effect on economic growth of China in the long run but is negative in the short run. This finding is consistent with the endogenous theory and other studies on the freedom-growth correlation. The opposite signs in the short and long run indicate that economic freedom progress in China does not have instantaneous effects on economic growth. The encouragement of more economically free policies will take time to be enforced, therefore, the effect may in fact hinder economic growth in the form of adverse socioeconomic impacts that occur in terms of investment freedom. Therefore, it may take time for the positive effects of economic freedom to take place and contribute to economic growth rate.

The speed of adjustment coefficient (ECT) is 0.95 showing the disturbance in the equilibrium that will take place as well as again confirming the long run correlation among variables. In addition, various diagnostic tests are performed to ensure the robustness and perfectness of the model and all tests confirm that the model is perfect (no autocorrelation, heteroskedasticity and the residuals are normally distributed).

Lastly, this research focused on studying the impact of the independent variables on the dependent variable on China in general. A more focused study on industries would be useful to determine whether the results differ among industries as well as countries. Economic growth is a complex phenomenon that requires much research. A recommendation of future research would be not to focus on only one individual country but more than one. Since the data is limited for these specific variables, it would be useful to examine the correlation through a cross sectional study using more than one country.

In addition, given the uniqueness of China's economy and the fact that the country seems to be an exception to the findings in corruption, law, economic freedom and economic growth literature, this raises the question as to 
what is the secret of China's impressive economic growth rates? Can the country continue to maintain its economy with the lack of economic freedom, sound legal and political institutions? These questions point out possible areas for future research to be conducted on China's unique economy.

The current study will be helpful and useful to future researchers at it has provided them with practical and theoretical implications of the variables in the study in the economic growth scenario. The findings emphasised the uniqueness of China's economy against theory and findings of the literature; the findings on environmental regulations and corruption were not consistent with the endogenous growth theory. While economic freedom may have proved to be consistent with the theory it had different results in the short and long run. This work can be extended in the future by incorporating and studying specific components of economic freedom rather than the overall score given to China.

The policy implication in this research is based on the findings of the effect of corruption. In order for the reduction of corruption to sustain economic growth, policymakers must create incentives for government officials to be proactive instead of providing them with an incentive of reaping the rewards of economic growth. The current incentive encourages officials to accept bribes and do whatever is necessary to promote growth. Thus, to break the cycle, incentives must be changed.

Lastly, there are several limitations faced in the study. Firstly, the main limitation of this research is the sample size; the limited number of observations and limited availability of required data. More reliable and accurate results would have been conducted if the sample size was greater than 21 observations. In addition, for the corruption and economic freedom indices used adopted from the World Bank and Fraser Institute respectively, there was some missing variables which was filled using linear interpolation. The results of the tests would have been more accurate if the data was complete. Lastly, the results of this research cannot be generalised beyond China to different countries or even different industries within a country.

\section{References}

Barnato, K. (2015). How China's anti-corruption drive is hurting growth. Retrieved from http://www.cnbc.com/2015/12/04/how-chinas-anti-corruption-drive-is-hurting-growth.html

Bayar, G. (2011). Causes Of Corruption: Dynamic Panel Data Analysis Of Some Post Soviet Countries And East Asian Countries. The Journal of Applied Business Research, 27(1). https://doi.org/10.19030/jabr.v27i1.912

Cagatay, S., \& Mihci, H. (2006). Degree of environmental stringency and the impact on trade patterns. Journal of Economic Studies, 33(1), 30-51. https://doi.org/10.1108/01443580610639884

Cai, X., Lu, Y., Wu, M., \& Yu, L. (2016). Does environmental regulation drive away inbound foreign direct investment? Evidence from a quasi-natural experiment in China. Journal of Development Economics, 73-85. https://doi.org/10.1016/j.jdeveco.2016.08.003

Compton, R. A., Giedeman, D. C., \& Hoover, G. A. (2011). Panel evidence on economic freedom and growth in the United States. European Journal of Political Economy, 27, 423-435. https://doi.org/10.1016/j.ejpoleco.2011.01.001

D'agostino, G., Dunne, J. P., \& Pieroni, L. (2016). Government Spending, Corruption and Economic Growth. World Development, 84, 190-205. https://doi.org/10.1016/j.worlddev.2016.03.011

Drury, A. C., Krieckhaus, J., \& Lusztig, M. (2006). Corruption, Democracy, and Economic Growth. International Political Science Review, 27(2), 121-136. https://doi.org/10.1177/0192512106061423

Dzhumashev, R. (2014). Corruption and growth: The role of governance, public spending, and economic development. Economic Modelling, 37, 202-215. https://doi.org/10.1016/j.econmod.2013.11.007

Farhadi, M., Islam, M. R., \& Moslehi, S. (2015). Economic Freedom and Productivity Growth in Resource-rich Economies. World Development, 72, 109-126. https://doi.org/10.1016/j.worlddev.2015.02.014

Farooq, A., Shahbaz, M., Arouri, M., \& Teulon, F. (2013). Does corruption impede economic growth in Pakistan? Economic Modelling, 35, 622-633. https://doi.org/10.1016/j.econmod.2013.08.019

Fraser Institute. (2017). Economic Freedom. Retrieved from https://www.fraserinstitute.org/economic-freedom/approach

Freckleton, M., Wright, A., \& Craigwell, R. (2012). Economic growth, foreign direct investment and corruption in developed and developing countries. Journal of Economic Studies, 39(6), 639-652. https://doi.org/10.1108/01443581211274593

Gharleghi, B., Najla, S., \& Chan, Y. F. B. (2015). Financial Integration and Common Currency Area In ASEAN. 
Journal of Economics, Business and Management, 3(1), 111-114. https://doi.org/10.7763/JOEBM.2015.V3.164

Huang, C. J. (2016). Is corruption bad for economic growth? Evidence from Asia-Pacific countries. North American Journal of Economics and Finance, 35, 247-256. https://doi.org/10.1016/j.najef.2015.10.013

Mendez, F., \& Sepulveda, F. (2006). Corruption, growth and political regimes: Cross country evidence. European Journal of Political Economy, 22, 82-98. https://doi.org/10.1016/j.ejpoleco.2005.04.005

Moussaa, M., Çahab, H., \& Karagöz, M. (2016). Review of Economic Freedom Impact on FDI: New Evidence from Fragile and Conflict Countries. Procedia Economics and Finance, 38, 163-173. https://doi.org/10.1016/S2212-5671(16)30187-3

OECD. (2016). How stringent are environmental policies? Retrieved from http://www.oecd.org/eco/greeneco/how-stringent-are-environmental-policies.htm

Pesaran, M., \& Shin, Y. (1995). An Autoregressive Distributed Lag Modelling Approach to Cointegration Analysis. Cambridge Working Papers in Economics.

Pulok, M. H., \& Ahmed, M. U. (2017). Does corruption matter for economic development? Long run evidence from Bangladesh. International Journal of Social Economics, 44(3), $350-361$. https://doi.org/10.1108/IJSE-05-2015-0132

Ramanathan, R., He, Q., Black, A., Ghobadian, A., \& Gallear, D. (2016). Environmental regulations, innovation and firm performance: A revisit of the Porter hypothesis. Journal of Cleaner Production, 1-14.

Saha, S., \& Ben-Ali, M. S. (2017). Corruption and Economic Development: New Evidence from the Middle Eastern and North African Countries. Economic Analysis and Policy, 54, 83-95. https://doi.org/10.1016/j.eap.2017.02.001

Stewart, R. B. (1993). Environmental Regulation and International Competitiveness. The Yale Law Journal, 102(8), 2039-2106. https://doi.org/10.2307/796859

Tang, D. et al. (2017). Environmental regulation efficiency and total factor productivity-Effect analysis based on Chinese data from 2003 to 2013. Ecological Indicators, 73, 312-318. https://doi.org/10.1016/j.ecolind.2016.08.040

Taylor, J. B. (2016). The role of the Chinese economy in the world economy: A U.S. perspective. China Economic Review, 40, 281-285. https://doi.org/10.1016/j.chieco.2016.07.004

Thomas, W. (2009). Do Environmental Regulations Impede Economic Growth? A Case Study of the Metal Finishing Industry in the South Coast Basin of Southern California. Economic Development Quarterly, 23(4), 329-341. https://doi.org/10.1177/0891242409343184

Transparency International. (2016). Corruption Perceptions Index: China. Retrieved from https://www.transparency.org/country/CHN

Wang, Y., \& Shen, N. (2016). Environmental regulation and environmental productivity: The case of China. Renewable and Sustainable Energy Reviews, 62, 758-766. https://doi.org/10.1016/j.rser.2016.05.048

Wang, Z., Zhang, B., \& Zeng, H. (2016). The effect of environmental regulation on external trade: Empirical evidences from Chinese economy. Journal of Cleaner Production, 114, 55-61. https://doi.org/10.1016/j.jclepro.2015.07.148

World Bank. (2017a). Global Economic Prospects. Washington DC: World Bank.

World Bank. (2017b). Worldwide Governance Indicators. Retrieved from http://info.worldbank.org/governance/wgi/index.aspx\#doc

Yuan, B., Ren, S., \& Chen, X. (2017). Can environmental regulation promote the coordinated development of economy and environment in China's manufacturing industry? A panel data analysis of 28 sub-sectors. Journal of Cleaner Production, 149, 11-24. https://doi.org/10.1016/j.jclepro.2017.02.065

\section{Copyrights}

Copyright for this article is retained by the author(s), with first publication rights granted to the journal.

This is an open-access article distributed under the terms and conditions of the Creative Commons Attribution license (http://creativecommons.org/licenses/by/4.0/). 